\title{
RANCANG BANGUN SISTEM AKUISISI DATA SUMBER RADIASI MELALUI UDARA MENGGUNAKAN ROBOT QUADCOPTER
}

\author{
Seno Pandu Ahmad ${ }^{1}$, Muhtadan ${ }^{1}$, Adi Abimanyu ${ }^{2}$ \\ 1) Sekolah Tinggi Teknologi Nuklir, Jalan Babarsari PO BOX 6101 Ykbb Yogyakarta \\ 55181, senopanduahmad@gmail.com,muhtadan@batan.go.id \\ 2) Pusat Sains dan Teknologi Akselerator, Jalan Babarsari PO BOX 6101 Ykbb \\ Yogyakarta 55181, abimanyu.adi@batan.go.id
}

\begin{abstract}
ABSTRAK
RANCANG BANGUN SISTEM AKUISISI DATA SUMBER RADIASI MELALUI UDARA MENGGUNAKAN ROBOT QUADCOPTER. Penelitian pendeteksian sumber radiasi menggunakan quadcopter beserta sistem akuisisinya belum dikembangkan, sehingga dirancang suatu sistem akuisisi data untuk pendeteksian sumber radiasi menggunakan quadcopter. Tujuan penelitian ini untuk pengembangan aplikasi program LabVIEW untuk akuisisi data sumber radiasi dan juga perancangan sistem informasi pendeteksian sumber radiasi dengan memetakan dalam kategori daerah radiasi dengan aplikasi Google Maps. Data radiasi dan posisi dari in-vehicle module quadcopter dikirimkan melalui sebuah transceiver NiceRF ke control room module, kemudian diproses dengan menggunakan program LabVIEW dan ditampilkan. Setelah proses pendeteksian selesai, data pergerakan dipetakan kembali sehingga didapat informasi jejak pergerakan quadcopter serta jarak antara titik awal pergerakan quadcopter dan sumber radiasi. Hasil pengujian menunjukkan bahwa program berhasil memberikan informasi posisi sumber radiasi yang terdeteksi. Program juga telah mampu memetakan pergerakan quadcopter, jarak antara operator quadcopter dan sumber radiasi yang terdeteksi pada pengujian pertama sebesar 20 meter dan pada pengujian kedua 30 meter. Persentase error dari perbandingan jarak pada pemetaan dengan jarak sebenarnya didapat pada pengujian pertama sebesar 3,8\% dan pada hasil pengujian kedua sebesar $7,14 \%$.
\end{abstract}

Kata kunci: akusisi data, sumber radiasi, quadcopter, LabVIEW, Google Maps

\begin{abstract}
DESIGN OF RADIATION SOURCE DATA ACQUISITION SYSTEM OVER THE AIR USING QUADCOPTER ROBOT. Research on detection of radiation sources using quadcopter with the acquisition system has not been developed, therefore the data acquisition system to detect radiation sources using quadcopter is designed. The purposes of this study is to develop a LabVIEW-based program for data acquisition of radiation sources and to design an information system for detection of radiation sources by mapping radiation areas with Google Maps. Data of radiation and position of the in-vehicle module in quadcopter was transmitted via NiceRF transceiver module to the control room, then processed and displayed in LabVIEW program. After the detection process was completed, data of quadcopter movement was mapped to get the path of the quadcopter and distance between operator and radiation source. Test results showed that the program succeeded in providing position of detected radiation. The program was also able to map the quadcopter movement. Distance between the operator and radiation source in the first final test was 20 meters and in the last final test 30 meters. The error percentage of comparison between distance from mapping and the real distance in the first test was 3,8\% and in the second test 7,14\%.
\end{abstract}

Keywords: data acquisition, radiation source, quadcopter, LabVIEW, Google Maps

\section{PENDAHULUAN}

Perkembangan teknologi nuklir dalam beberapa tahun ini cukup pesat, yang meliputi bidang pertanian, kesehatan, industri, dan energi. Pemanfaatan tenaga nuklir harus mendapat pengawasan yang cermat agar selalu mengikuti segala ketentuan di bidang keselamatan tenaga nuklir sehingga tidak menimbulkan bahaya radiasi terhadap pekerja, masyarakat, dan lingkungan hidup 
Sumber radiasi gamma yang digunakan dalam pekerjaan industri pada umumnya berbentuk sumber terbungkus dengan aktivitas cukup besar, sehingga mempunyai potensi bahaya paparan radiasi cukup besar seperti hilang atau tercecernya sumber radiasi akibat human error. Proses pencarian sumber radiasi dalam kasus semacam itu umumnya dilakukan dengan cara penyisiran laju paparan radiasi daerah yang diperkirakan merupakan lokasi hilangnya sumber radiasi [1].

Pada umumnya, pengukuran laju paparan radiasi dilakukan dengan cara operator mendekati objek sambil membawa alat yang digunakan untuk mengukur laju paparan radiasi. Hal ini mengakibatkan potensi risiko bahaya radiasi terhadap operator semakin besar apabila objek yang diukur memiliki intensitas radiasi yang besar. Beberapa cara pengukuran radiasi untuk mengurangi potensi terpapar radiasi yang cukup besar telah banyak dikembangkan, antara lain dengan menggunakan long tong surveymeter dan menggunakan robot hexapod yang dilengkapi surveymeter. Tetapi metode-metode tersebut hanya efektif jika digunakan pada lokasi datar. Pada lokasi yang tidak datar hal-hal itu cukup sulit dilakukan. Metode lain yang digunakan adalah dengan cara mengangkut alat monitor radiasi (surveymeter) dengan menggunakan quadcopter yang dikendalikan oleh operator. Dengan metode ini pengukuran radiasi menjadi lebih mudah dan lebih aman.

Pada proses pendeteksian/monitor radiasi dengan menggunakan quadcopter, data yang didapat berupa data radiasi dan data posisi dalam bentuk mentah yang kemudian diproses oleh sistem akuisisi menjadi informasi yang berguna bagi operator dan petugas proteksi radiasi.

Penelitian ini dilakukan untuk membantu mendeteksi sumber radiasi pada kondisi yang sulit atau bahkan tidak bisa dijangkau manusia, memungkinkan operator untuk mendeteksi paparan radiasi pada medan atau track apapun dari jarak jauh tanpa mendekati objek radiasi yang dideteksi. Data paparan radiasi dan posisi akan ditransmisikan dari quadcopter dengan menggunakan suatu transmitter dan diterima oleh sebuah receiver, kemudian diakuisisi oleh komputer menggunakan program LabVIEW. Data tersebut dibuat untuk memetakan lokasi pendeteksian ke dalam kategori daerah radiasi di Google Maps dengan menggunakan aplikasi Google Maps API.

\section{DASAR TEORI}

\section{Sistem Akuisisi Data}

Sistem akuisisi data dapat didefinisikan sebagai suatu sistem untuk mengambil, mengumpulkan, dan menyiapkan data, kemudian memprosesnya hingga menghasilkan data yang diinginkan. Sistem akuisisi data memudahkan manusia untuk mencerna suatu informasi atau data yang diterima berupa besaran fisis pada suatu proses tertentu sehingga dapat melakukan suatu proses lebih lanjut dengan lebih mudah [2]. Akuisisi data merupakan proses di mana data dari sensor diubah menjadi sinyal-sinyal listrik yang dikonversi lebih lanjut menjadi bentuk digital untuk pemrosesan dan analisis oleh komputer [3].

\section{Radiasi}

Radiasi adalah cara perambatan energi dari suatu sumber energi ke lingkungannya tanpa perantara. Radiasi juga dapat diartikan sebagai energi yang dipancarkan dalam bentuk partikel atau gelombang.

Berdasarkan muatan listrik yang dikandungnya, radiasi dapat dibagi menjadi radiasi pengion dan radiasi non-pengion. Radiasi pengion adalah radiasi yang, apabila menumbuk atau menabrak sesuatu, akan memunculkan partikel bermuatan listrik yang disebut ion. Radiasi pengion disebut juga radiasi atom atau radiasi nuklir. Radiasi nonpengion adalah radiasi yang tidak menimbulkan ionisasi. Termasuk ke dalam radiasi non-pengion adalah gelombang radio, gelombang mikro, inframerah, cahaya tampak dan ultraviolet.

Dosis efektif rata-rata sebesar $20 \mathrm{mSv}$ (dua puluh milisievert) per tahun dalam periode 5 (lima) tahun, sehingga dosis yang terakumulasi dalam 5 (lima) tahun tidak boleh melebihi $100 \mathrm{mSv}$ (seratus milisievert) [4]. Paparan didefinisikan sebagai kemampuan radiasi sinar- $X$ atau gamma untuk menimbulkan ionisasi di udara dalam volume tertentu, dalam satuan internasional satuan paparannya adalah $\mathrm{C} / \mathrm{kg}$, sedangkan dalam satuan lama adalah roentgen ( $\mathrm{R})$. Besar paparan per satuan waktu, yang diberi simbol $\dot{X}$, disebut laju paparan. Satuan untuk laju paparan dalam satuan internasional adalah C/kg.jam dan dalam satuan lama adalah $\mathrm{R} / \mathrm{jam}$. Adapun konversi untuk satuan roentgen ke dalam sievert adalah $1 \mathrm{~Sv}=100 \mathrm{R}$ [5]. 


\section{Global Positioning System}

Global Positioning System (GPS) adalah sistem navigasi berbasiskan satelit yang saling berhubungan pada orbitnya. Untuk dapat mengetahui posisi suatu objek, maka diperlukan alat yang diberi nama GPS receiver yang berfungsi untuk menerima sinyal yang dikirim dari satelit GPS. Posisi diubah menjadi titik yang dikenal dengan nama Way-point, pada akhirnya berupa titik-titik koordinat lintang dan bujur dari posisi objek atau suatu lokasi pada peta elektronik.

Pada umumnya, sistem tracking menggunakan GPS. Dengan GPS koordinat lintang dan bujur dari suatu tempat atau titik di permukaan bumi dapat diketahui sehingga dapat ditentukan posisinya. Posisi tersebut dapat ditentukan dengan menggunakan GPS receiver yang merupakan koordinat lintang dan bujur dari GPS receiver itu sendiri. GPS receiver akan memberikan data keluaran berupa data posisi (koordinat lintang dan bujur), waktu, kecepatan, serta arah dari GPS receiver tersebut [6].

\section{Google Maps dan Google Static Maps API}

Google Maps adalah layanan peta digital dari Google yang dapat diakses secara gratis oleh siapa saja. Google Maps pada umumnya digunakan pada aplikasi tracking dan akses peta statis digital dengan menggunakan Google Statics Maps API.

Prinsip dari Google Static Maps API adalah mengembalikan gambar (dalam format GIF, PNG, atau JPEG) dari permintaan HTTP melalui URL. Untuk setiap permintaan, pengguna dapat menentukan lokasi peta, ukuran gambar, tingkat zoom, jenis peta, dan penempatan penanda opsional di lokasi pada peta. Selain itu pengguna mendapatkan label penanda pengguna menggunakan karakter alfanumerik. Jika API gambar statis Maps digunakan di luar aplikasi berbasis web (seperti browser), maka link harus disertakan menunjuk ke lokasi yang ditampilkan dalam browser web atau aplikasi Google Maps [7].

\section{Quadcopter}

Quadcopter adalah robot penjelajah udara atau biasa disebut Unmanned Aerial Vehicle (UAV), yang termasuk kategori UAV mikro dengan ciri khusus yang mudah dikenali, yaitu memiliki empat buah baling-baling motor sebagai pernggeraknya. Penggunaan empat buah baling-baling memudahkan quadcopter untuk bermanuver sehingga dengan cepat dapat bergerak ke segala arah. Hal ini mejadi salah satu kelebihan quadcopter. Selain empat buah baling-baling, quadcopter dapat dilengkapi dengan sensor, di antaranya sensor Global Positioning System (GPS) yang digunakan untuk bernavigasi [8].

\section{METODE PENELITIAN}

Sistem monitoring laju paparan radiasi menggunakan quadcopter terdiri dari subsistem In Vehicle Module (IVM), subsistem Control Operator Module (COM) dan subsistem Control Room Module (CRM) sebagaimana ditunjukkan pada Gambar 1. Prinsip kerja sistem ini adalah subsistem IVM (monitor radiasi yang diangkut oleh quadcopter) akan terbang untuk memantau laju paparan radiasi. IVM dikendalikan oleh operator dengan menggunakan subsistem COM melalui remote control dan modul pemantau dalam bentuk informasi audio. Data yang diperoleh IVM dikirimkan secara nirkabel menggunakan frekuensi radio ke CRM untuk diakusisi dan ditampilkan dalam peta digital pada komputer sebagaimana ditunjukkan pada Gambar 2.

Proses akusisi data pada CRM diawali dengan konfigurasi parameter komunikasi serial yang akan digunakan, yang meliputi port, baud rate, stop bits, parity dan flow control. Proses selanjutnya adalah pembacaan data yang dikirimkan oleh IVM. Data yang diproses oleh CRM hanya data dengan header karakter "R". Data tersebut kemudian diparsing (dipisahkan) menjadi data laju paparan radiasi, bujur, lintang, dan ketinggian, kemudian status radiasi ditampilkan dan data yang telah di-parsing dimasukkan ke dalam tabel serta dilakukan pemetaan pergerakan. Ketika proses monitoring selesai dilakukan, data tersebut akan secara otomatis tersimpan dalam suatu laporan yang berbentuk .doc (aplikasi Microsoft. Word). Diagram alir proses akuisisi pada CRM ditunjukkan pada Gambar 3. 


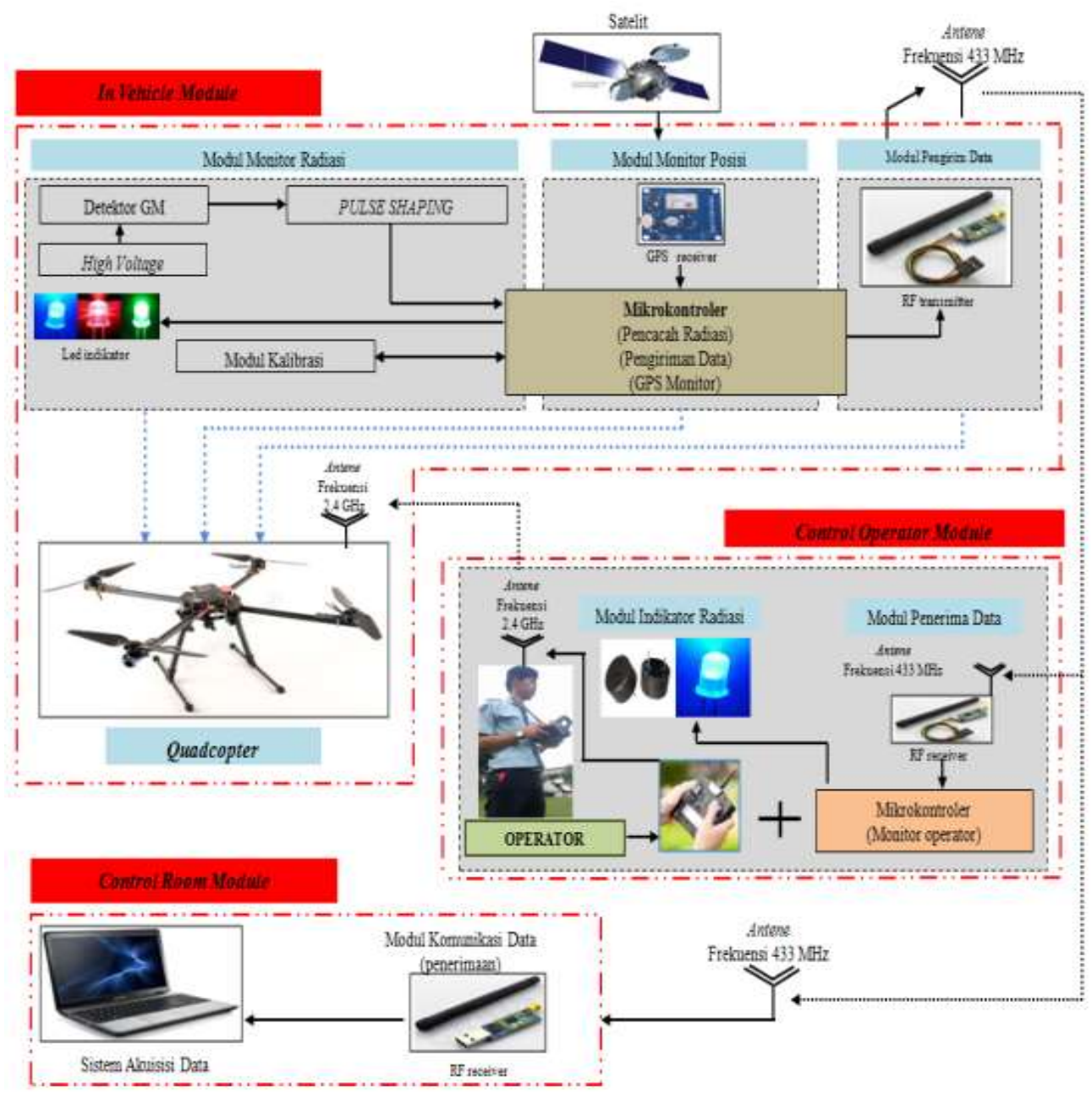

Gambar 1. Blok Diagram Sistem Monitoring Laju Paparan Radiasi Menggunakan Quadcopter

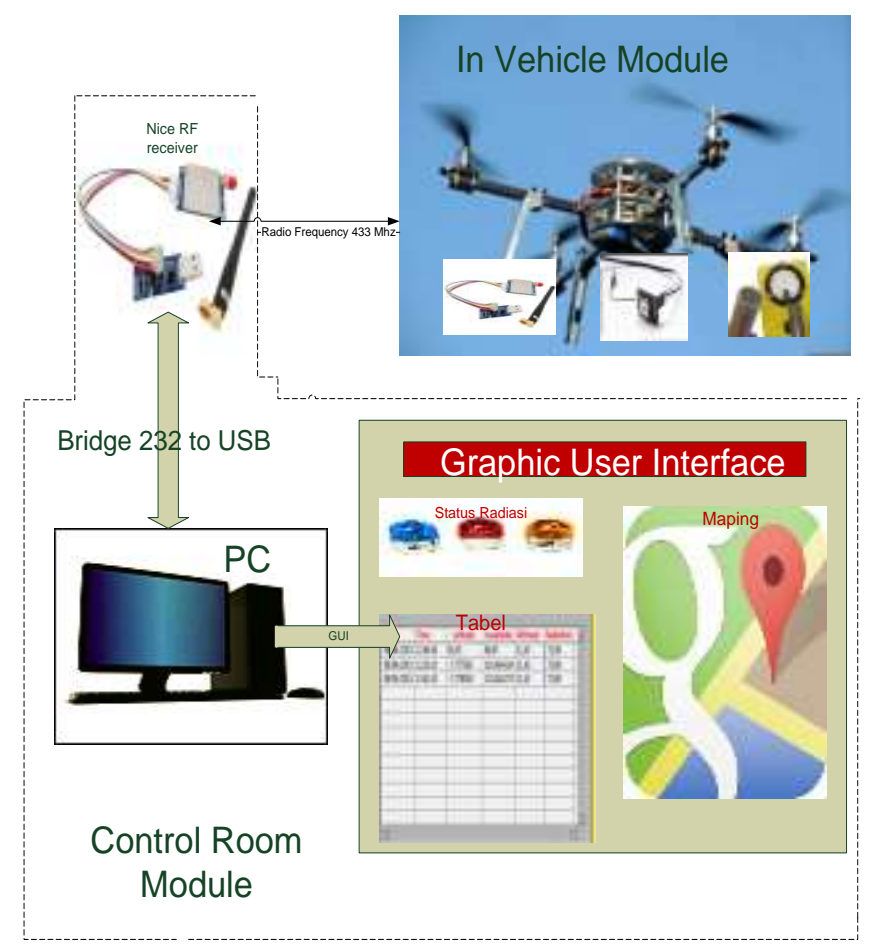

Gambar 2. Blok Diagram CRM 


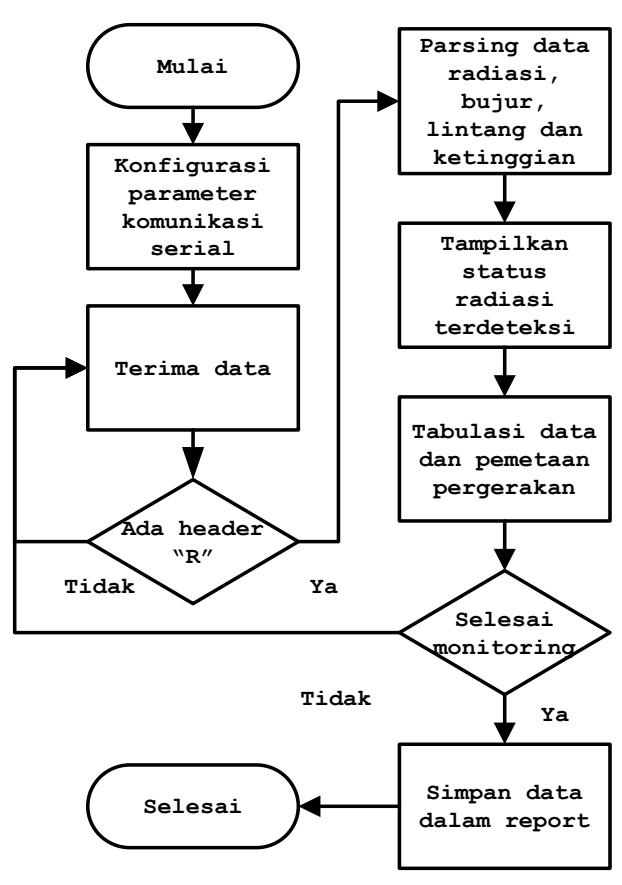

Gambar 3. Diagram Alir CRM

\section{HASIL DAN PEMBAHASAN}

\section{Pengujian Terpadu Seluruh Sistem}

Pengujian bertujuan untuk mengetahui apakah sistem akusisi yang dirancang-bangun mampu mengakusisi data yang dikirimkan oleh IVM secara nirkabel. Pengujian dilakukan dengan cara mengirimkan data secara langsung dari IVM yang sedang melakukan proses monitoring radiasi. Pengujian ini dilakukan pada dua lokasi yang berbeda, yaitu di depan Gedung 03 PSTA dan di lapangan rumput sebelah utara STTN-BATAN. Hasil pengujian untuk setiap lokasi disajikan pada Tabel 1 dan 2 , sedangkan hasil pemetaan data ditunjukkan pada Gambar 4 dan 5.

Berdasarkan data hasil pengujian, terlihat bahwa sistem akusisi yang dirancang telah mampu memproses dan mengakusisi data yang dikirimkan oleh IVM secara nirkabel menggunakan frekuensi radio dengan jeda waktu pengiriman setiap data 2 detik. Pada pengujian pertama didapat titik awal pergerakan berada pada koordinat bujur lintang $-7,777933,110,414400$, yang juga merupakan titik operator quadcopter berada. Titik di mana terdeteksi sumber radiasi berada pada koordinat bujur lintang -7,777845, 110,41428. Pada pengujian kedua, titik awal pergerakan berada pada koordinat bujur lintang -7.778055 , 110.412352, dan titik di mana terdeteksi sumber radiasi berada pada koordinat bujur lintang -7.777882, 110.412532 .

Pengujian pertama dilakukan di depan Gedung 3 PSTA-BATAN dengan menggunakan koneksi wi-fi dari lantai 1 Gedung 3 PSTA-BATAN, sedangkan pengujian kedua dilakukan di sebelah utara gedung STTNBATAN. Pada dua pengujian ini terdapat perbedaan kecepatan koneksi internet yang digunakan untuk proses permintaan peta digital dari Google Maps. Perbedaan ini terlihat pada saat operator di control room melakukan monitor di komputer. Pada pengujian pertama yang menggunakan koneksi wi-fi di Gedung 3 PSTA-BATAN dengan kecepatan 48.0 Mbps, proses load peta digital dari Google Maps tidak terkendala buffering dari koneksi sehingga perubahan pergerakan quadcopter yang diwakilkan oleh baloon (marker) sangatlah smooth, dalam arti pergerakan dari satu titik ke titik berikutnya dapat tampil dan terpantau keseluruhan oleh operator di control room. Pada pengujian kedua yang menggunakan modem Smartfren dengan kecepatan 3.1 Mbps, proses load peta digital dari Google Maps terkendala buffering dari koneksi sehingga perubahan pergerakan quadcopter pada tampila monitor yang diwakilkan oleh baloon (marker) kurang smooth, dalam arti pergerakan dari titik ke titik berikutnya tidak terpantau secara keseluruhan, terdapat lompatan antar-posisi pergerakan sehingga pada saat proses monitoring pergerakan quadcopter yang diwakilkan oleh baloon (marker) tidak bergerak sesuai urutan pergerakan di lapangan.

Jarak dari starting point terhadap sumber radiasi berhasil didapatkan setelah dilakukannya proses pemetaan. Pada pengujian terpadu yang pertama, jarak awal pergerakan ke sumber radiasi yang terdeteksi sebesar 20 meter dan pada pengujian kedua sebesar 30 meter. Pengujian akurasi pemetaan juga dilakukan untuk mengetahui perbandingan jarak yang didapat dari titik lintang bujur dengan menggunakan rumus haversine dengan jarak sebenarnya. Pada pengujian pertama dengan rumus haversine didapat jarak antara dua posisi lintang bujur sebesar 20 meter, sedangkan pada pengukuran jarak sebenarnya didapat sebesar 20,8 meter. Pada pengujian kedua dengan rumus haversine didapat jarak antara dua posisi lintang bujur sebesar 30 meter, sedangkan pada pengukuran jarak 
sebenarnya didapat sebesar 28 meter. Persentase error dari perbandingan jarak pada pemetaan dan jarak sebenarnya pada hasil pengujian pertama sebesar $3,8 \%$ dan pada hasil pengujian kedua sebesar $7,14 \%$.

Tabel 1. Hasil Pengujian di Depan Gedung 03 PSTA

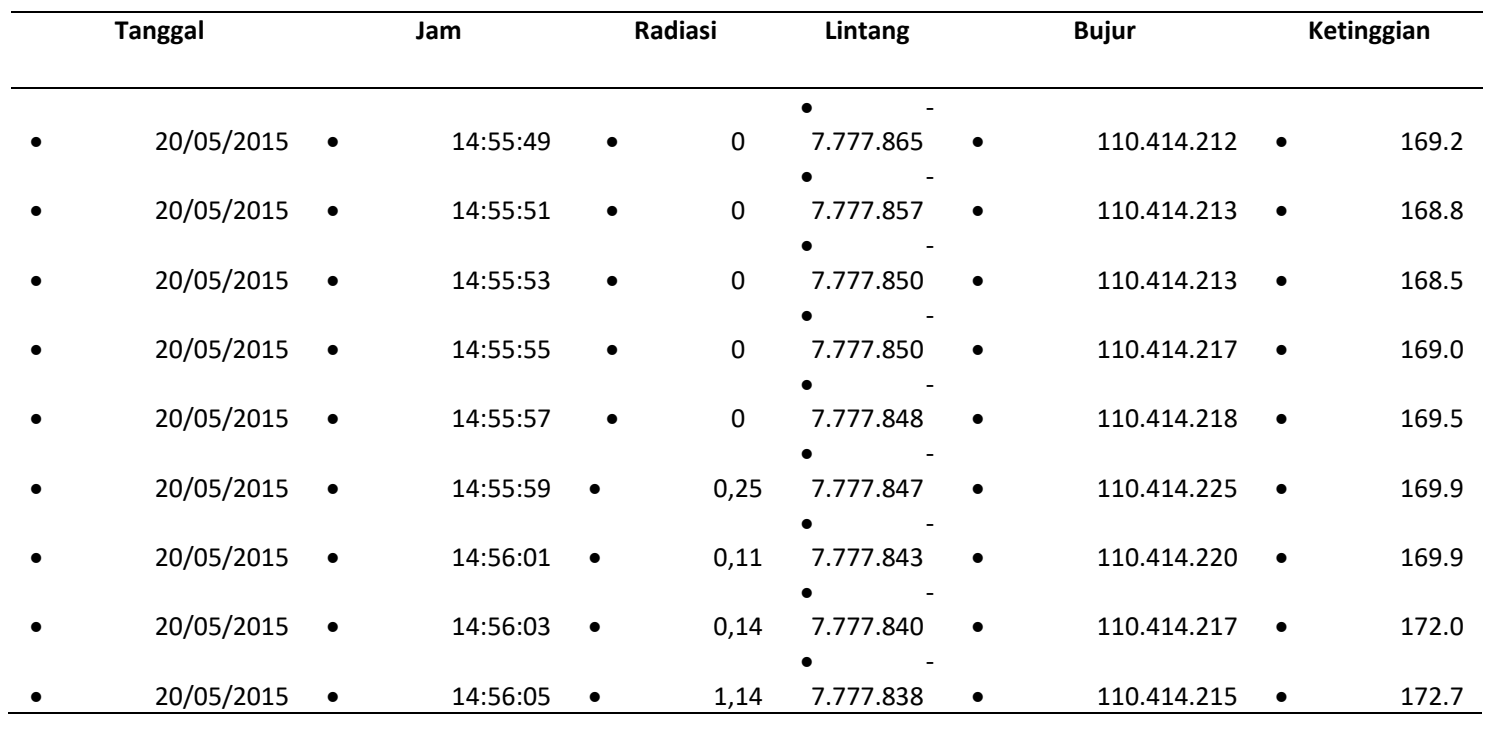

Tabel 2. Hasil Pengujian di Lapangan Rumput Utara STTN-BATAN

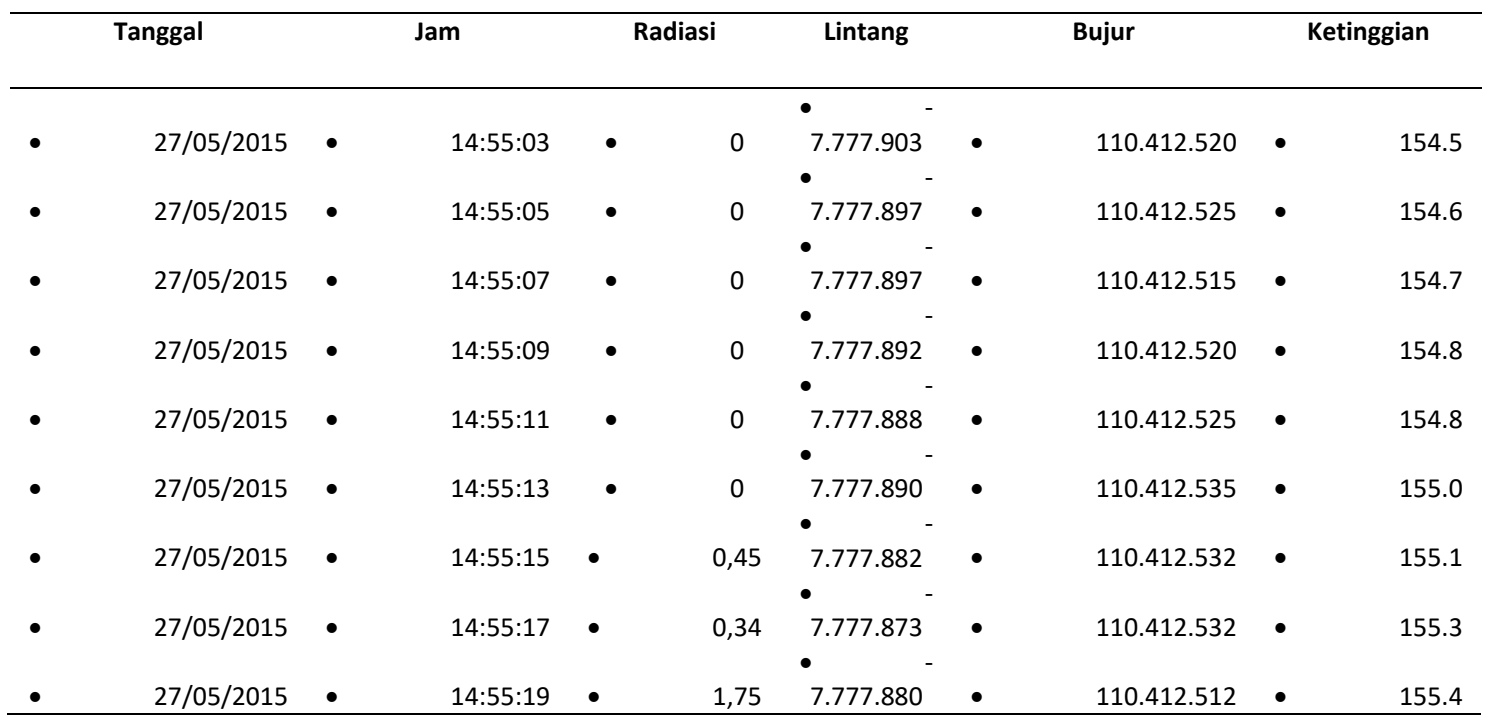




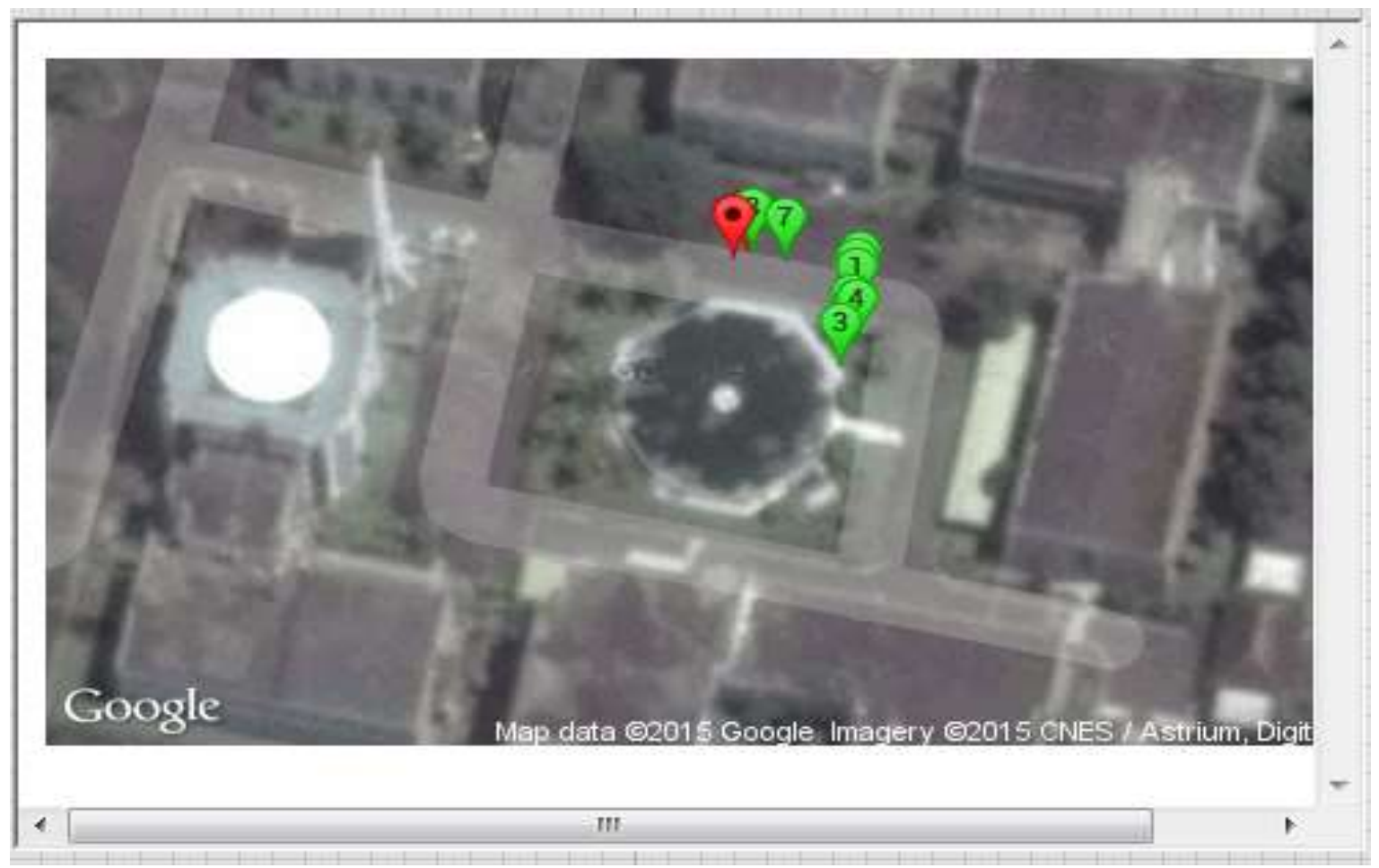

Gambar 4. Pemetaan Lokasi Depan Gedung 03 PSTA

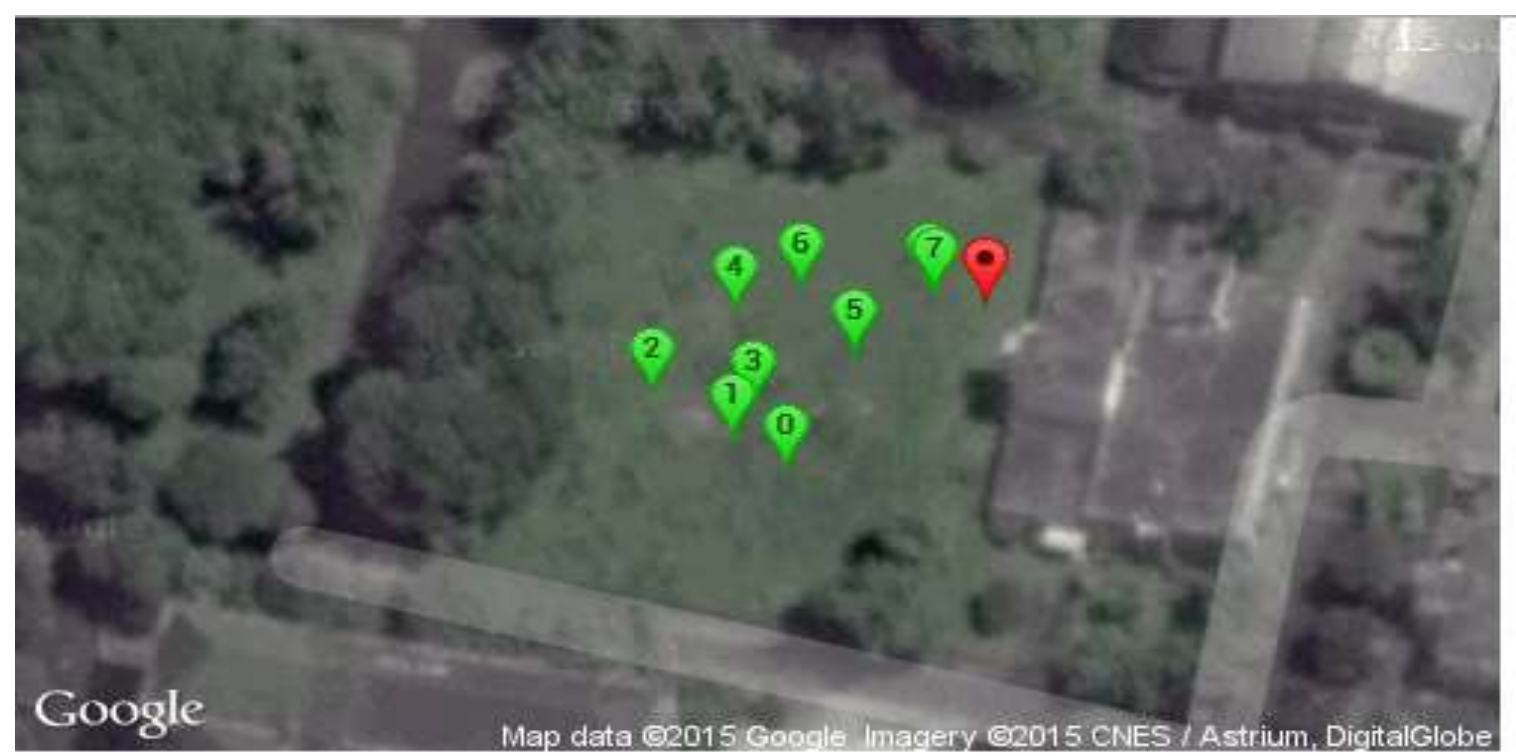

Gambar 5. Pemetaan Lokasi Lapangan Rumput Utara STTN-BATAN 


\section{KESIMPULAN}

1. Berhasil dibuat program untuk mengakuisisi data paparan sumber radiasi yang dideteksi quadcopter dengan menggunakan program LabVIEW.

2. Berhasil dirancang sebuah sistem informasi pemantauan radiasi dengan memetakan data posisi dan lokasi pendeteksian ke dalam kategori daerah radiasi di Google Maps dengan menggunakan aplikasi Google Maps API yang ditampilkan di program LabVIEW. Pada pengujian pertama nilai paparan radiasi mulai terdeteksi pada titik lintang bujur $7,777847,110,414225$ dan pada pengujian kedua laju paparan radiasi mulai terdeteksi pada titik lintang bujur -7,777882, 110,412532. Pemetaan pergerakan quadcopter menggunakan multiple baloon dan jejak berupa garis dapat dilakukan dengan maksimal input data posisi pada syntax Google Maps sebanyak 28 data posisi. Jarak operator dari sumber yang terdeteksi dapat diukur dengan menggunakan rumus haversine, pada pengujian pertama didapat jarak sebesar 20 meter, pada pengujian kedua sebesar 30 meter. Persentase error dari perbandingan jarak pada pemetaan dengan jarak sebenarnya didapat pada pengujian pertama sebesar $3,8 \%$ dan pada hasil pengujian kedua sebesar 7,14\%.

3. Komunikasi data secara wireless telah berhasil dilakukan dengan menggunakan Nice RF dengan frekuensi $433 \mathrm{MHz}$.

4. Penggunaan koneksi wi-fi dengan kecepatan 48 Mbps lebih memudahkan dalam proses monitoring perubahan pergerakan quadcopter di control room.

\section{DAFTAR PUSTAKA}

1. Alauddin, A. B. 2012. Rancang Bangun Sistem Akuisisi Data Untuk Pencarian Sumber Radiasi Nuklir Menggunakan Robot Hexapod. STTN-BATAN.

2. Mustika, I. W., Litasari, Abimanyu, A. \& Utama, F. P. 2015. Perancangan Sistem Komunikasi dengan SMS Tersandi dan Pelacakan Posisi Berbasis Web untuk Mendukung Sistem Monitor Laju Paparan Radiasi pada Transportasi Zat Radioaktif.

3. Bolton, W. 2004. Sistem Instrumentasi dan Kontrol.
4. Bapeten 2013. Perka Nomor 4 Pasal 14 Nilai Batas Dosis, Bapeten.

5. STTN-BATAN 2015. Pelatihan Petugas Proteksi Radiasi Industri Tingkat 1.

6. Nataliana, D. 2013. Perancangan Dan Realisasi Sistem Transmisi Data GPS Menggunakan Teknologi SMS (Short Messaging Service) Sebagai Aplikasi Sistem Personal Tracking. Elkomika Jurnal Teknik Elektronika Itenas.

7. Google. 2015. Statics Maps Api V2 Developers Guide [Online]. Available: https://developers.google.com/maps/docum entation/staticmaps/.

8. Elektro. 2014. Quadcopter [Online]. Available: http://zonaelektro.net/quadcopter 